\title{
DETECTION OF Rhizomucor pusillus ON SUNFLOWER SEED
}

Lević, J. , Ivanović, D., Stanković, S., Milivojević, M.,

Vukadinović, R. and Stepanić, A.

Maize Research Institute, Zemun Polje, S. Bajića 1, 11185 Belgrade, Republic of Serbia

Received: August 20, 2013

Accepted: December 05, 2013

\section{SUMMARY}

The accelerated ageing test method (AA), agar plate method (A) and blotter method (B) have been used to detect the Rhizomucor pusillus and other mycobita on 24 samples of sunflower seed. Sterilised and unsterilised sunflower seeds have been incubated at $25^{\circ} \mathrm{C}$ and $42^{\circ} \mathrm{C}$ in the dark for 72 and 144 hours. The fungus was not detected in any sample at $25^{\circ} \mathrm{C}$, not even after $144 \mathrm{~h}$ incubation of seeds. The fungal frequency ranged from 58.3 (B method) to $75.0 \%$ (A method) and from $4.2 \%$ (B method) to $16.7 \%$ (AA method) after $72 \mathrm{~h}$ incubation of unsterilised and sterilised samples at $42^{\circ} \mathrm{C}$, respectively. The fungal incidence was 25.5\% (AA method), 21.9\% (A method) and $20.3 \%$ (B method) after $72 \mathrm{~h}$ incubation of unsterilised seed, and $2 \%$ on sterilised seed in all three applied methods. By extended incubation of unsterilised and sterilised seeds up to $144 \mathrm{~h}$ at $42^{\circ} \mathrm{C}$ the frequency and incidence of the fungus did not significantly change. The results of the present research show that the AA test method, widely applied in seed longevity testing, can be used as a simple and efficient method for the detection of $R$. pusillus as well as other mycobiota on sunflower seed. Furthermore, these are the first data on determining the presence of R. pusillus in Serbia.

Key words: Rhizomucor pusillus, methods, incidence, sunflower seed

\section{INTRODUCTION}

Rhizomucor pusillus (Lindt) Schipper (syn. Mucor pusillus Lindt) is globally widespread and has been found in the UK, Chad, former Czechoslovakia, South Africa, Indonesia, India, Japan, the USA, Nigeria and Australia (Salar and Aneja, 2007). The fungus has been mainly detected on various types of seeds of cacao, barley, oat, maize, wheat, soya bean, rape, lupine and flax, groundnuts, nuts, and on fruits, different types of compost, municipal waste, horse dung, guayule, hay, herbs, bird's nests, air, water, submerged mud and soil (Nedzinskiene and Asakaviciute,

* Corresponding author: Fax: +381 113756 707; e-mail: jlevic@mrizp.rs 
2011; Salar and Aneja, 2007; Lugauskas et al., 2006a; Kačergius et al., 2005; Řezáčová and Kubátová, 2005; Adebajo and Popoola, 2003; Straatsma et al., 1994; El-Hissy et al., 1990; Niles, 1981). There are little data in available literature on the occurrence of $R$. pusillus in sunflower seed (Tansey, 1984).

According to Kačergius et al. (2005) the fungus is predominant in the air of stored grain, fruit storehouses and processed products. Furthermore, it is one of the major micobiota of stored vegetables (Adebanjo and Shopeju, 1993). The incidence of the fungus increased from the third (3-5\%) to the ninth month $(7-11 \%)$ in kola nuts during storage (Adebajo and Popoola, 2003). R. pusillus prevailed in one or more types of different ingredients of poultry feed (soya bean meal, ground maize, cotton-seed cake, wheat bran and fish meal) (Moharram et al., 1989), in various foodstuff of floral origin (Lugauskas et al., 2006b) or in buckwheat mass during different technological stages of groats production (Lugauskas et al., 2006a).

R. pusillus is the only Rhizomucor species that causes diseases in humans (Chayakulkeeree et al., 2006). Human infections caused by this fungus have been most frequently reported in the European Union and the United States, then in Canada, and one case in Australia, Brazil and Japan (Gomes at al., 2011). It has been reported in cases of pulmonary, disseminated and cutaneous types of infection (Ellis et al., 2007). Moreover, it has been more often associated with animal diseases, especially bovine abortion (Ellis et al., 2007).

$R$. pusillus is a beneficial fungal species because certain enzymes produced by it are extensively used in the production of rennet in cheese manufacture (Neelakantan et al., 1999). In addition, the fungus has been used in retting of flax for manufacturing natural fibres in the United States and Europe (Henriksson et al., 1997). Generally, Rhizomucor species might be a prime candidate for the glycerol and biomass production (Millatia et al., 2005).

There are no data on the detection of $R$. pusillus in papers printed in scientific journals in Serbia. However, we have detected an intensive development of this fungus on one sample in our previous tests on sunflower seed longevity by the accelerated ageing (AA) test method. Considering the above facts the aim of the investigation was to study some aspects of test methods used in detecting this fungus and to estimate its frequency and incidence on sunflower seed in Serbia.

\section{MATERIAL AND METHODS}

After the 2011 harvest, 24 samples of sunflower seeds were collected in 17 locations in Serbia. Samples were packed in paper bags and stored at $16^{\circ} \mathrm{C}$ until tested for the presence of $R$. pusillus.

The detection of $R$. pusillus by the accelerated ageing (AA) test method (Hampton and TeKrony, 1995), widely used in seed longevity studies, was compared with 
conventional seed test methods such as the agar plate medium (A) and the blotter (B) method (Mathur and Kongsdal, 2003) with some modifications.

According to the description of the AA test given by Hampton and TeKrony (1995) seeds were placed on the wire mesh screen tray, which was then inserted into the inner chamber - a plastic box (Hoffman Manufacturing Jefferson, OR, USA) containing $50 \mathrm{ml}$ of distilled water (Figure 1a-c). Twenty five seeds per box were placed apart at a uniform distance to avoid contamination or fungal spread from infected to uninfected seeds (Figure 1e-f).

Malt extract agar (MEA) containing $20 \mathrm{~g}$ of malt extract, $20 \mathrm{~g}$ of agar and 1000 $\mathrm{ml}$ of distilled water adjusted to $\mathrm{pH} 6.5$ was used for the agar plate method (Smith and Onions, 1983). Five seeds were placed in $90 \mathrm{~mm}$ Petri dish on the agar surface.

The initial preparation of the modified blotter method involves making sets of two and one layer of Whatman filter paper grade 1 of the appropriate size to be placed on the bottom and the lid of Petri dishes, respectively. The filter papers on the bottom of each $90 \mathrm{~mm}$ Petri dish were soaked with $5 \mathrm{ml}$ and the filter paper on the lid with $2 \mathrm{ml}$ of sterile water. Five seeds were distributed on the well watersoaked filter paper. At the first screening after $72 \mathrm{~h}$ incubation, sterile water was added if it was necessary to maintain filter paper moistened.

Fifty seeds each with and without pre-treatment at the incubation temperature of $25^{\circ} \mathrm{C}$ and $42^{\circ} \mathrm{C}$ were used for the fungal detection in each of the applied test methods. All samples with pre-treatments were surface-sterilised in $1 \%$ sodium hypochlorite for $3 \mathrm{~min}$, rinsed three times with distilled water and then dried between two layers of soft paper. In all cases, the seeds were incubated in the dark for $144 \mathrm{~h}$.

The first screening of the fungal presence was done after the $72 \mathrm{~h}$ and the final after the $144 \mathrm{~h}$ incubation. The preliminary identification of the $R$. pusillus on incubated seeds was done with a stereomicroscope $(\times 15-25)$ according to formed sporangiophores and heads with spores (Figure 2g). In order to reliably identify the fungus, the fragments of colonies developed on incubated seed (Figure 1g) were transferred to potato dextrose agar (PDA) and incubated under chamber conditions at $25^{\circ} \pm 1^{\circ} \mathrm{C}$ in the dark. Fungal subcultivation on carnation leaf agar (CLA) and incubation at $36 \pm 1^{\circ} \mathrm{C}$ and $42 \pm 1{ }^{\circ} \mathrm{C}$ was used for fungal morphological studies. Media PDA and CLA were prepared according to Burgess et al. (1994). The fungus was identified after seven days as described by Ellis et al. (2007).

Beside $R$. pusillus, some other fungal species were identified on incubated sunflower seeds according to the description given by von Arx (1981).

The fungal frequency $(\mathrm{F})$ and incidence (I) were estimated by following equations:

$$
\begin{aligned}
& F(\%)=\frac{\text { number of seed samples in which a species occurred }}{\text { total number of seed samples }} \times 100 \\
& \mathrm{I}(\%)=\frac{\text { number of seeds in which a species occurred }}{\text { total number of seeds) }} \times 100
\end{aligned}
$$

The incidence rate of $R$. Pusillus in seed samples was classified as low (0 to $\leq 20$ ), moderate ( $>21$ to $\leq 50$ ) and high (over 50\%) (Lević et al., 2012). 

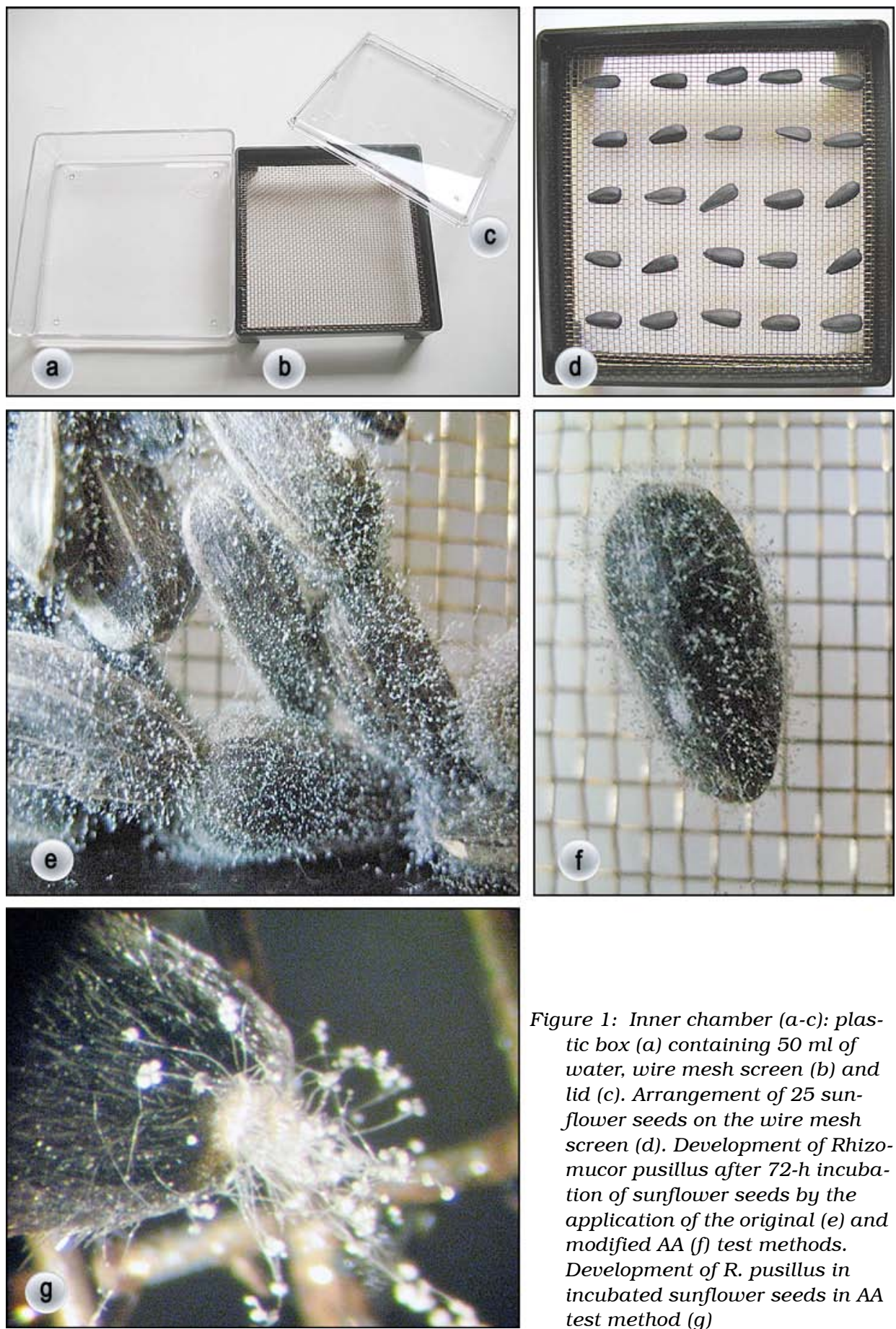

Figure 1: Inner chamber (a-c): plastic box (a) containing $50 \mathrm{ml}$ of water, wire mesh screen (b) and lid (c). Arrangement of 25 sunflower seeds on the wire mesh screen (d). Development of Rhizomucor pusillus after 72-h incubation of sunflower seeds by the application of the original (e) and modified AA (f) test methods. Development of $R$. pusillus in incubated sunflower seeds in $A A$ test method $(g)$ 
The correlation between the incidences of $R$. pusillis determined by three different test methods was calculated using the Spearman's rank correlation coefficient (Zar, 1972). The rank correlation coefficient $\left(r_{s}\right)$ is expressed as: $r_{\mathrm{s}}=1-6 \Sigma d^{2} /\left(n^{3}\right.$ $n$ ), where $n$ is the number of measurements in each of the two variates in correlation, $\Sigma d^{2}=\Sigma_{i=1}^{n} d_{i}^{2}$, and $d_{i}$ is the ranked difference between the $i^{\text {th }}$ measurement for the two varieties. Student's test was used for testing significance of $r_{s}$, as: $t=r_{s} / \sqrt{\left(1-r_{s}^{2}\right) /(n-2)}$, with $n-2$ of freedom.

\section{RESULTS}

\section{Detection of R. pusillus}

The fungus isolated from colonies developed on incubated seed (Figure 1g) formed sympodially branched sporangiophores, globose sporangia with oval to pear-shaped columellae, hyaline, smooth-walled, globose to subglobose sporangiospores and rarely rhizoids on CLA at $36 \pm 1^{\circ} \mathrm{C}$ and $42 \pm 1^{\circ} \mathrm{C}$. The size of sporangiospores increased several times before germination.

$R$. pusillus was identified in 22 and 21 out of 24 samples after 72 and $144 \mathrm{~h}$ seed incubation at $42^{\circ} \mathrm{C}$, respectively (Table 1). However, the fungus was not detected in any sample when seed was incubated at $25^{\circ} \mathrm{C}$ (data are not presented).

AA method. The frequency of $R$. pusillus determined on unsterilised seeds by the AA method was $66.7 \%$ and $70.8 \%$ after 72 and $144 \mathrm{~h}$ incubation, respectively (Table 1). The incidence of the fungus was on average $25.5 \%$ after $72 \mathrm{~h}$ and somewhat higher (32.6\%) after $144 \mathrm{~h}$ incubation. Depending on a sunflower seed sample, the fungal incidence varied from 2 to $100 \%$ after both 72 and $144 \mathrm{~h}$ incubation. In the majority of samples (11-13 samples) of unsterilised seeds the fungal incidence after $72 \mathrm{~h}$ was low $(\leq 20 \%)$, while it was moderate $(21-50 \%)$ in up to two samples and high ( $>50 \%$ ) in up to three samples. After $144 \mathrm{~h}$ incubation of unsterilised seed at $42^{\circ} \mathrm{C}$ the number of seed samples with a low fungal incidence reduced (from 11 to seven samples), while the number of samples with moderate and high incidence increased (from two to six and from three to four, respectively, Burgess et al., 1994).

A method. The fungal frequency determined by the A method was at the same level (75.9\%) after 72 and $144 \mathrm{~h}$ incubation of unsterilised seeds (Table 1). The variation range of incidence was not significantly changed after $144 \mathrm{~h}$ incubation (2$100 \%$ ) in relation to $72 \mathrm{~h}$ incubation (2-98\%). On average, the incidence of the fungus after 72 and $144 \mathrm{~h}$ incubation determined by the A method amounted to $21.9 \%$ and $30.9 \%$, respectively.

B method. The application of the B method showed that the $R$. pusillus frequency on unsterilised sunflower seeds after $72 \mathrm{~h}$ incubation was somewhat greater than after $144 \mathrm{~h}$ incubation (58.3\% vs. 54.2\%) (Table 1). Similarly, the variation of the fungal incidence was fairly greater after $72 \mathrm{~h}$ incubation than after $144 \mathrm{~h}$ incu- 
bation (2-100\% vs. 2-98\%). However, the incidence determined by the B method was, on average, greater after $144 \mathrm{~h}(24.6 \%)$ than after $72 \mathrm{~h}$ incubation $(20.3 \%)$.

Table 1: Frequency and incidence of R. pusillus determined by three different test methods after 72 and $144 \mathrm{~h}$ incubation of unsterilised and sterilised sunflower seeds at $42^{\circ} \mathrm{C}$

\begin{tabular}{|c|c|c|c|c|c|c|c|c|c|c|c|c|c|}
\hline \multirow{4}{*}{$\begin{array}{l}\text { Sample } \\
\text { No. }\end{array}$} & \multirow{4}{*}{ Location } & \multicolumn{12}{|c|}{ R. pusillus incidence (\%) } \\
\hline & & \multicolumn{6}{|c|}{ Unsterilised seed } & \multicolumn{6}{|c|}{ Sterilised seed } \\
\hline & & \multicolumn{3}{|c|}{$72 \mathrm{~h}$} & \multicolumn{3}{|c|}{$144 \mathrm{~h}$} & \multicolumn{3}{|c|}{$72 \mathrm{~h}$} & \multicolumn{3}{|c|}{$144 \mathrm{~h}$} \\
\hline & & AA & A & $B$ & AA & $\mathrm{A}$ & $\mathrm{B}$ & AA & $A$ & $B$ & AA & $\mathrm{A}$ & $\mathrm{B}$ \\
\hline 2216 & B. Palanka & 8 & 16 & 12 & 26 & 8 & 8 & & 2 & & & & \\
\hline 2187 & Begeč & & 2 & & & 2 & & & & & & & \\
\hline 2225 & Čoka & 46 & 48 & 18 & 42 & 82 & 42 & & & 2 & & & 4 \\
\hline 2227 & Čoka & 50 & 24 & 38 & 60 & 84 & 36 & & & & 2 & & \\
\hline 2229 & Čoka & 100 & 98 & 100 & 96 & 100 & 98 & & & & & & \\
\hline 2185 & Feketić & & & & & & & & & & & & \\
\hline 2218 & Futog & & & 4 & & & & & & & & & \\
\hline 2219 & Futog & 2 & 2 & & 28 & 8 & & 2 & 2 & & & 2 & \\
\hline 2223 & Ilinci & 8 & 4 & 2 & 30 & 4 & 2 & & & & & & \\
\hline 2224 & Ilinci & & 6 & 2 & & 10 & 4 & & & & & & \\
\hline 2182 & Irig & 2 & 4 & 4 & 10 & 20 & 2 & & & & 2 & & 2 \\
\hline 2220 & Jamena & 6 & 4 & & 4 & 4 & 8 & & 2 & & & & \\
\hline 2221 & Jamena & & 2 & 2 & & 8 & 10 & & & & & & \\
\hline 2172 & Kovačica & 10 & 2 & & 8 & 18 & & & & & 2 & & \\
\hline 2230 & Kovilj & 64 & 82 & 72 & 72 & 94 & 82 & & & & & & 2 \\
\hline 2184 & Lugovo & & & & & & & & & & & & \\
\hline 2174 & Samoš & 4 & & 2 & 10 & & 2 & & & & & & \\
\hline 2222 & Šid & 4 & 4 & & 34 & 12 & & 2 & & & 8 & & \\
\hline 2190 & Sirig & 14 & 8 & 2 & 36 & 10 & & & & & & & \\
\hline 2189 & Sivac & & 2 & & & 4 & & & & & & & \\
\hline 2188 & Srbobran & 4 & & & 16 & & & 2 & & & 2 & & \\
\hline 2217 & Srbobran & 12 & 18 & 8 & 8 & 6 & 8 & 2 & & & & & \\
\hline 2231 & Srbobran & 74 & 68 & 18 & 68 & 82 & 18 & & & & & & \\
\hline 2183 & Vrbas & & & & 6 & & & & & & & & \\
\hline Incidenc & e $(\%)^{\star}$ & 25.5 & 21.9 & 20.3 & 32.6 & 30.9 & 24.6 & 2.0 & 2.0 & 2.0 & 3.2 & 2.0 & 2.7 \\
\hline Frequen & Icy (\%) & 66.7 & 75.0 & 58.3 & 70.8 & 75.0 & 54.2 & 16.7 & 12.5 & 4.2 & 20.8 & 4.2 & 12.5 \\
\hline
\end{tabular}

Both, frequency and incidence of $R$. pusillus were drastically decreased on sunflower seeds when seeds had been sterilised (Table 1). The presence of the fungus on sterilised seeds was mostly determined by the AA method (up to $20.8 \%$ after 144 $\mathrm{h}$ incubation) in relation to remaining two methods (up to $12.5 \%$ ). On average, the 
fungal incidence determined on sterilised seeds did not significantly varied (2.0$3.2 \%$ ) depending on either applied method or incubation period.

Table 2: Frequency and incidence of fungi other than R. pusillus and bacteria determined by three different methods after 72 and $144 \mathrm{~h}$ incubation of unsterilised and sterilised sunflower seeds at $25^{\circ} \mathrm{C}$ and $42^{\circ} \mathrm{C}$

\begin{tabular}{|c|c|c|c|c|c|c|c|c|c|c|c|c|c|}
\hline \multirow[t]{4}{*}{ Species } & \multirow[t]{4}{*}{$\mathrm{IP}(\mathrm{h})$} & \multicolumn{12}{|c|}{ Fungal incidence (\%) } \\
\hline & & \multicolumn{6}{|c|}{ Unsterilised seed } & \multicolumn{6}{|c|}{ Sterilised seed } \\
\hline & & \multicolumn{3}{|c|}{$25^{\circ} \mathrm{C}$} & \multicolumn{3}{|c|}{$42^{\circ} \mathrm{C}$} & \multicolumn{3}{|c|}{$25^{\circ} \mathrm{C}$} & \multicolumn{3}{|c|}{$42^{\circ} \mathrm{C}$} \\
\hline & & AA & A & B & AA & A & B & AA & A & B & AA & A & B \\
\hline \multirow[t]{2}{*}{ Alternaria spp. } & 72 & 83.6 & 82.3 & 76.2 & & & & 59.3 & 65.2 & 56.4 & & & \\
\hline & 144 & 84.5 & 87.7 & 83.4 & & & & 69.5 & 66.5 & 69.0 & & & \\
\hline \multirow[t]{2}{*}{ A. flavus } & 72 & 15.3 & 12.5 & 4.0 & 14.7 & 16.0 & 4.8 & 6.8 & 7.0 & 3.2 & 11.0 & 12.1 & 3.0 \\
\hline & 144 & 14.5 & 6.4 & 3.6 & 22.5 & 12.2 & 6.9 & 8.3 & 4.6 & 7.2 & 16.4 & 8.5 & 3.0 \\
\hline \multirow[t]{2}{*}{ A. niger } & 72 & 8.0 & 3.0 & 6.0 & 6.0 & 9.3 & 2.3 & 2.0 & 5.0 & 4.8 & 4.9 & 7.0 & 2.0 \\
\hline & 144 & 5.5 & 5.3 & 6.8 & 12.6 & 14.0 & 6.6 & 4.0 & 4.9 & 4.0 & 12.7 & 6.2 & 3.1 \\
\hline \multirow[t]{2}{*}{ Aspergillus spp. } & 72 & 24.0 & 28.0 & 6.0 & 4.9 & 3.0 & 3.0 & 2.0 & 2.0 & & 2.0 & & 2.0 \\
\hline & 144 & 21.0 & 3.4 & 10.0 & 7.2 & 6.8 & 4.0 & 7.6 & 3.0 & 2.0 & 6.7 & 3.0 & 3.3 \\
\hline \multirow[t]{2}{*}{ Cladosporium spp. } & 72 & 17.6 & 29.9 & 31.2 & & & & 9.4 & 14.9 & 15.7 & & & \\
\hline & 144 & 20.1 & 31.4 & 17.8 & & & & 9.2 & 16.4 & 5.8 & & & \\
\hline \multirow[t]{2}{*}{ Penicillium spp. } & 72 & 4.0 & 6.0 & 3.3 & 4.6 & 4.5 & 4.0 & 4.0 & 2.5 & & 3.2 & 2.0 & \\
\hline & 144 & 10.9 & 3.0 & 8.5 & 39.5 & 14.3 & 4.6 & 6.0 & 2.7 & & 15.1 & 5.0 & 4.5 \\
\hline \multirow[t]{2}{*}{ Rhizopus spp. } & 72 & 17.4 & 26.0 & 22.9 & & 4.9 & & 2.0 & 3.6 & 4.0 & & & \\
\hline & 144 & 25.0 & 26.7 & 19.3 & & 4.7 & & 2.0 & 5.4 & 3.5 & & & \\
\hline \multirow[t]{2}{*}{ Other fungi } & 72 & 4.0 & 5.0 & 3.3 & 18.6 & 13.8 & 9.4 & & 2.0 & 2.4 & 13.0 & 3.5 & 3.3 \\
\hline & 144 & 6.0 & 6.0 & 8.0 & 27.5 & 16.1 & 9.6 & 2.0 & 4.3 & 8.5 & 14.2 & 2.0 & 3.0 \\
\hline \multirow[t]{2}{*}{ Bacteria } & 72 & & & 2.0 & & 12.1 & 9.7 & & & 2.0 & & 7.5 & 4.9 \\
\hline & 144 & & 2.5 & 24.0 & & 11.6 & 3.8 & & & 2.0 & & 6.0 & 1.7 \\
\hline \multicolumn{14}{|l|}{ Incidence (\%)* } \\
\hline & 72 & 21.7 & 24.1 & 17.2 & 9.8 & 9.1 & 5.5 & 12.2 & 12.8 & 12.6 & 6.8 & 6.4 & 3.0 \\
\hline & 144 & 23.4 & 19.2 & 20.2 & 21.9 & 11.4 & 5.9 & 13.6 & 13.5 & 12.8 & 13.0 & 5.1 & 3.1 \\
\hline \multicolumn{14}{|l|}{ Frequency (\%)** } \\
\hline \multirow{2}{*}{ Min } & 72 & 4.2 & 8.3 & 12.5 & 37.5 & 4.2 & 20.8 & 4.2 & 4.2 & 4.2 & 4.2 & 8.3 & 8.3 \\
\hline & 144 & 33.3 & 8.3 & 8.3 & 45.8 & 29.2 & 33.3 & 8.3 & 12.5 & 4.2 & 8.3 & 4.2 & 12.5 \\
\hline \multirow{2}{*}{ Max } & 72 & 100.0 & 100.0 & 100.0 & 79.2 & 79.2 & 54.2 & 100.0 & 91.7 & 100.0 & 29.2 & 25.0 & 25.0 \\
\hline & 144 & 100.0 & 100.0 & 100.0 & 91.7 & 87.5 & 90.0 & 100.0 & 100.0 & 100.0 & 54.2 & 45.8 & 33.3 \\
\hline \multirow{2}{*}{ Average } & 72 & 38.5 & 47.4 & 40.7 & 62.5 & 52.4 & 37.5 & 29.2 & 21.4 & 29.2 & 18.3 & 16.7 & 17.5 \\
\hline & 144 & 46.9 & 45.8 & 38.1 & 74.9 & 63.1 & 54.6 & 34.4 & 37.5 & 27.1 & 34.2 & 27.1 & 22.2 \\
\hline \multicolumn{14}{|c|}{$\begin{array}{l}\text { IP (h) - Incubation period (hour) } \\
\text { AA - Accelerated ageing test method } \\
\text { A - Agar plate method } \\
\text { B - Blotter method } \\
\text { * - Average of positive samples }\end{array}$} \\
\hline
\end{tabular}

\section{Detection of fungi other than $R$. pusillus}

Aside from $R$. pusillus, the frequency and incidence of other fungi, as well as bacteria, were determined in the present study. Generally, the frequency and inci- 
dence of fungi and bacteria were not more significantly changed by prolonged incubation of unsterilised and sterilised seeds. The majority had already reached their maximum after $72 \mathrm{~h}$ incubation (Table 2 ).

The frequency of fungi other than R. pusillus determined by AA, A and B methods on unsterilised seeds after $72 \mathrm{~h}$ incubation at $25^{\circ} \mathrm{C}$ ranged from $4.2-12.5$ to $100 \%$ or on average from $38.5 \%$ to $47.4 \%$ (Table 2 ). In addition, the frequency of this group of fungi significantly changed at $42^{\circ} \mathrm{C}$, hence minimum, maximum and average values amounted to $37.5,79.2$ and $62.5 \%$, respectively. Furthermore, the frequency of these on sterilised seeds incubated at $25^{\circ} \mathrm{C}$ did not change significantly in comparison to unsterilised seeds. However, these changes were significant when sterilised seeds were incubated at $42^{\circ} \mathrm{C}$, as minimum, maximum and average values were lower.

Table 3: Spearman's rank correlation coefficient calculated between incidence of $R$. pusillus ${ }^{\mathrm{a}}$ and fungi other than $R$. pusillus and bacteria ${ }^{\mathrm{b}}$ determined by three different methods under various temperature conditions and incubation periods of unsterilised seed

\begin{tabular}{|c|c|c|c|c|c|c|c|}
\hline \multirow{3}{*}{ Fungi } & \multirow{3}{*}{ Method } & \multicolumn{6}{|c|}{ Incubation period } \\
\hline & & \multicolumn{3}{|c|}{$72 \mathrm{~h}$} & \multicolumn{3}{|c|}{$144 \mathrm{~h}$} \\
\hline & & AA & $A$ & $B$ & AA & $\mathrm{A}$ & $B$ \\
\hline \multicolumn{8}{|c|}{ Temperature $25^{\circ} \mathrm{C}$} \\
\hline & AA & - & - & - & - & - & - \\
\hline \multirow[t]{3}{*}{ R. pusillus ${ }^{\mathrm{a}}$} & $A$ & & - & - & - & - & - \\
\hline & B & & & - & - & - & - \\
\hline & $\overline{\mathrm{AA}}$ & - & $0.842^{\star \star}$ & $0.633^{\star \star}$ & - & $0.825^{\star \star}$ & $0.916^{\star \star}$ \\
\hline \multirow[t]{2}{*}{ Other fungi and bacteria ${ }^{b}$} & $A$ & & - & 0.691 ** & & - & $0.800 * *$ \\
\hline & B & & & - & & & - \\
\hline \multicolumn{8}{|c|}{ Temperature $42^{\circ} \mathrm{C}$} \\
\hline \multirow{4}{*}{ R. pusillus ${ }^{\mathrm{a}}$} & $\overline{\mathrm{AA}}$ & - & $0.807^{* \star}$ & $0.690^{\star \star}$ & - & $0.710^{\star \star}$ & $0.591^{\star \star}$ \\
\hline & A & & - & $0.883^{\star *}$ & & - & $0.691 * *$ \\
\hline & $\mathrm{B}$ & & & - & & & - \\
\hline & AA & - & $0.825^{\star \star}$ & $0.687^{\star \star}$ & - & $0.702^{\star \star}$ & $0.820^{\star \star}$ \\
\hline \multirow[t]{2}{*}{ Other fungi and bacteria ${ }^{b}$} & $A$ & & - & $0.841 * *$ & & - & $0.833^{* \star}$ \\
\hline & B & & & - & & & - \\
\hline
\end{tabular}

${ }^{2}$ The correlation was calculated on the basis of data presented in Table 1

${ }^{\mathrm{b}}$ The correlation was calculated on the basis of data presented in Table 2

AA - Accelerated ageing test method

A - Agar plate method

B - Blotter method

** - Significant at $P<0.01$

In regard to all fungi other than $R$. pusillus, the greatest incidence (76.2-83.6\%) was identified for the Alternaria species on unsterilised sunflower seeds after just $72 \mathrm{~h}$ incubation at $25^{\circ} \mathrm{C}$ (Table 2 ). Under such conditions of incubation of unsterilised seeds the mean incidence was determined in species of the genera Aspergillus, Cladosporium and Rhizopus. The incidence of the majority of fungi incubated at $42^{\circ} \mathrm{C}$ was low with the exception of species of the genera Aspergillus and Penicil- 
lium. Furthermore, the incidence of other fungal species but Alternaria spp. was significantly reduced on sterilised seeds, particularly on those incubated at $42^{\circ} \mathrm{C}$. Bacteria developed more intensively on both unsterilised and sterilised seeds when the incubation temperature was $42^{\circ} \mathrm{C}$.

\section{Correlation}

The Spearman's rank correlation coefficient indicated a significant positive correlation between the incidence of $R$. pusillus determined by the AA, A or B methods (Table 3). The high rank correlation coefficient also confirmed consent of results for the incidence of fungi other than $R$. pusillus determined by different methods applied.

\section{DISCUSSION}

Obtained results indicate that the $R$. pusillus is a widespread species in sunflower seeds in Serbia. These results were confirmed by the application of three different methods (AA, A and B) under laboratory conditions. In addition to advantages in the detection of $R$. pusillus, each of these methods had certain disadvantages. Correlation coefficients showed that the most similar results had been gained between AA and A test methods, while in some cases the greater difference in results had been obtained by AA and $B$ test methods.

There are several advantages in the application of the accelerated ageing test methods (AA) in the detection of $R$. pusillus in relation to remaining two methods. This method is easy to apply because it is not necessary to prepare the medium or filter paper, then it provides high moisture throughout the incubation period and prevents both spreading of the fungus from one to another seed and the development of bacteria (Table 2). Based on the specific development on incubated seeds (Figure 1g), this fungus was easily detectable at a low magnifying of the stereomicroscope, even in the case when it was associated with other fungal species. The fungus mostly developed on the upper part of the sunflower seed.

The advantages stated for the accelerated ageing test method in the detection of R. pusillus were disadvantages for the agar plate test method (A). Spreading of the fungus from one to another seed was a particular disadvantage of the A method. The consequence of this could be that positive results were significantly higher than the actual one. The advantage of the A method was in the fact that fungi on this medium formed colonies specific for each of them and that they was visually recognisable.

The advantage of the blotter test method (B) was in the fact that fungi, particularly $R$. pusillus, did not spread from a seed to a seed and that in the majority of cases they form colonies specific for each of them. The disadvantage of this test method was that it took a long time to prepare filter paper and to maintain required moisture during incubation. Although, filter paper was moistened with the same 
amount of water in all cases, in some Petri dishes it was necessary additionally to moisten filter paper after $72 \mathrm{~h}$.

Surface sterilisation of seeds with $1 \%$ sodium hypochlorite for 3 minutes significantly reduced the frequency and incidence of $R$. pusillus (Table 1), but this did not happen with some other fungi (Tables 2). In certain cases, the frequency, i.e., incidence of $R$. pusillus, depending on the applied test method and the duration of the incubation period, was decreased from $75.0 \%$ to $4.2 \%$, i.e., from $30.9 \%$ to $2.0 \%$, respectively. These results indicate that the fungus predominantly developed on the surface of sunflower seeds, but they have to be proven by further detailed studies.

Furthermore, gained results show that the temperature of seed incubation was a more significant factor in the detection of $R$. pusillus than the applied test method or the duration of the incubation period were. Namely, the fungus was detected on sunflower seeds at the incubated at the temperature of $42^{\circ} \mathrm{C}$. The frequency and incidence of the fungus detected after $72 \mathrm{~h}$ of seed incubation at this temperature did not significantly differ from the corresponding values recorded after $144 \mathrm{~h}$ incubation.

The fact that $R$. pusillus did not develop on sunflower seeds incubated at $25^{\circ} \mathrm{C}$ can be explained by the competition of other species of fungi. Namely, other fungal species developed at this temperature, particularly fungi of the genus Alternara that formed a very dense mycelium. In contrast to these fungal species, $R$. pusillus developed very slowly at this temperature, while its mycelium was very sparse.

According to the literature data, $R$. pusillus has been reported to be a thermophilic and hydrophilic zygomycete (Tansey, 1984; Johri et al., 1999; Ellis et al., 2007). Our results confirmed thermophilic properties of $R$. pusillus because the fungus had been determined when the sunflower seeds had been incubated at $42^{\circ} \mathrm{C}$, but not at $25^{\circ} \mathrm{C}$. Furthermore, the morphological properties of the fungus isolated from incubated sunflower seeds corresponded to $R$. pusillus described Ellis et al. (2007).

The obtained results show that the AA test method is suitable for the rapid and efficient determination of the $R$. pusillus presence in sunflower seeds under laboratory conditions. The application of this test method offered data on the differences between samples and the maximum value in the fungal incidence in a very short time $(72 \mathrm{~h})$ on both unsterilised and sterilised seeds. Furthermore, this test method simultaneously provided the necessary conditions for the development of $R$. Pusillus. The incidence, as well as, the frequency of the fungus indicated that the $R$. pusillus was a widespread species in sunflower seeds in Serbia. These were the first results on the occurrence of this fungus in Serbia. According to our opinion and experience, this test method was also effective for the identification of this fungus in seeds of other plant species, but this have to be confirmed in further research. 
In conclusion, the obtained results indicate that the presence of $R$. pusillus on sunflower seeds can easily be detected if some of the basic environmental requirements for fungal growth indoors are fulfilled. First of all, it refers to the temperature that has to be $42^{\circ} \mathrm{C}$, while the environmental moisture is the second important requirement. The fungus is mostly eliminated by surface sterilisation of seeds. Nevertheless, the fungus may be important from the sanitary point of view if fresh sunflower seeds are used, or during storage under extreme conditions or in certain cases in food processing.

\section{ACKNOWLEDGEMENTS}

The study is a part of the research performed within the scope of the Project No. TR-31023 financially supported by the Ministry of Education and Science of the Republic of Serbia.

\section{REFERENCES}

Adebajo, L.O. and Popoola, O.J., 2003. Mycoflora and mycotoxins in kolanuts during storage. African Journal of Biotechnology 2(10): 365-368.

Adebanjo, A. and Shopeju, E., 1993. Sources and mycoflora associated with some sundried vegetables in storage. International Biodeterioration and Biodegradation 31: 255-263.

Arx, J.A. von, 1981. The Genera of Fungi Sporulating in Pure Culture. J. Cramer, Germany, pp. 424.

Burgess, L.W., Summerell, B.A., Bullock, S., Gott, K.P. and Backhouse, D., 1994. Laboratory Manual for Fusarium Research. Sydney: University of Sydney and Royal Botanic Gardens, Australia.

Chayakulkeeree, M., Ghannoum, M.A. and Perfect, J.R., 2006. Zygomycosis: the re-emerging fungal infection. European Journal of Clinic Microbiology and Infectious Disease 25: 215229.

El-Hissy, F.T., Moharram, A.M. and El-Zayat, S.A., 1990. Studies on the mycoflora of Aswan High Dam Lake, Egypt: monthly variations. Journal of Basic Microbiology 30: 81-94.

Ellis, D., Davis, S., Alexiou, H., Handke, R. and Bartley, R., 2007. Descriptions of Medical Fungi. ( $2^{\text {nd }}$ ed.). Adelaide: Bibliography, Australia, pp. 204.

Gomes, M.Z.R., Russell, E.L. and Kontoyiannis, D.P., 2011. Mucormycosis caused by unusual mucormycetes, Non-Rhizopus, -Mucor, and -Lichtheimia species. Clinical Microbiology Reviews 24: 411-445.

Hampton, J.G. and TeKrony, D.M., 1995. Handbook of Vigour Test Methods. ( ${ }^{\text {rd }}$ ed.). Zürich: The International Seed Testing Association, Switzeland, pp. 117.

Henriksson, G., Akin, D., Hanlin, R.T., Rodriguez, C., Archibald, D.D., Rigsby, L.L. and Eriksson, K-E.L., 1997. Identification and retting efficiencies of fungi isolated from dewretted flax in the United States and Europe. Applied and Environmental Microbiology 63 : 3950-3956.

Johri, B.N., Satyanarayana, T. and Olsen, J., 1999. Thermophilic Moulds in Biotechnology. Dirdrech: Kluwer Academic Publishers, The Netherlans, pp. 355.

Kačergius, A., Lugauskas, A., Levinskaité, L., Varbaité, R., Mankevičiené, A., Bakutis, B., Baliukoneiné V., Brūkštiené, D., 2005. Screening of micromycetes producing toxic substances under various conditions. Botanica Lithuanica Suppl. 7: 65-75.

Lević, J., Stanković, S., Krnjaja, V., Bočarov-Stančić, A. and Ivanović, D., 2012. Distribution frequency and incidence of seed-borne pathogens of some cereals and industrial crops in Serbia. Pesticide and Phytomedicine 27: 33-40.

Lugauskas, A., Raila, A., Railiene M. and Raudoniene V., 2006a. Toxic micromycetes in grain raw material during its processing. Annals of Agricultural and Environmental Medicine 13: $147-161$. 
Lugauskas, A., Raudonienè, V., Varnaitè, R., Dirginčiutė, V., Baliukonienè, V. and Bakutis, B., 2006b. Ecological and sanitary significance of micromycetes brought from abroad with various foodstuff of floral origin. Ekologija 3: 28-41.

Mathur, S.B. and Kongsdal, O., 2003. Common Laboratory Seed Testing Methods for Detecting Fungi. First edition, International Seed Testing Association, Bassersdorf, CH-Switzerland, pp. 425.

Millatia, R., Edebob, L. and Taherzadehc, M.J., 2005. Performance of Rhizopus, Rhizomucor, and Mucor in ethanol production from glucose, xylose, and wood hydrolyzates. Enzyme and Microbial Technology 36: 294-300.

Moharram, A.M., Abdel-Gawad, K.M., Megalla, S.E. and Mahmoud, A.L., 1989. Fungal flora of poultry feedstuff ingredients. Journal of Basic Microbiology 29: 491-499.

Nedzinskiene, L.T.R. and Asakaviciute, R., 2011. Development of fungi on Lupinus angustifolius L. and Lupinus luteus L. Research in Plant Biology 1: 20-29.

Neelakantan, S., Mohanty, A.K. and Kaushik, J.K., 1999. Production and use of microbial enzimes for dairy processing. Current Science 77: 143-148.

Niles, E.V., 1981. Microflora of imported cocoa beans. Journal of Stored Products Research 17: $147-150$.

Řezáčová, V. and Kubátová, A., 2005. Saprobic microfungi in tea based on Camellia sinensis and on other dried herbs. Czech Mycology 57: 79-89.

Salar, R.K. and Aneja, K.R., 2007. Thermophilic fungi: taxonomy and biogeography. Journal of Agricultural Technology 3(1): 77-107.

Smith, D. and Onions, A.H.S., 1983. The Preservation and Maintenance of Living Fungi. Page Bros (Norwich) Ltd, Mile Cross Lane, Norwich, Norfolk, pp. 51.

Straatsma, G., Samson, R.A. Olijnsma, T.W., Op den Camp, H.J.M., Gerrits, J.P.G. and van Griensven, L.J., 1994. Ecology of thermophilic fungi in mushroom compost, with emphasis on Scytalidium thermophilum and growth stimulation of Agaricus bisporus mycelium. Applied and Environmental Microbiology 60: 454-458.

Tansey, M.R., 1984. Efficient isolation of thermophilic and thermotolerant mucoralean fungi. Mycopathologia 85: 3-42.

Zar, J.H., 1972. Significance of the Spearman rank correlation coefficient. Journal of American Statistical Association 67: 578-580. 